University at Buffalo School of Law

Digital Commons @ University at Buffalo School of Law

Journal Articles

Faculty Scholarship

$1-1-1981$

\title{
Language, Audience, and the Transformation of Disputes
}

Lynn Mather

University at Buffalo School of Law

Barbara Yngvesson

Hampshire College

Follow this and additional works at: https://digitalcommons.law.buffalo.edu/journal_articles

Part of the Law and Society Commons

\section{Recommended Citation}

Lynn Mather \& Barbara Yngvesson, Language, Audience, and the Transformation of Disputes, 15 Law \& Soc'y Rev. 775 (1981).

Available at: https://digitalcommons.law.buffalo.edu/journal_articles/859

(C) 1981 Law and Society Association. Reproduced with permission.

\section{C) ${ }_{\text {COPYRIGHT }}^{\text {N }}$}

This Article is brought to you for free and open access by the Faculty Scholarship at Digital Commons @ University at Buffalo School of Law. It has been accepted for inclusion in Journal Articles by an authorized administrator of Digital Commons @ University at Buffalo School of Law. For more information, please contact lawscholar@buffalo.edu. 


\title{
LANGUAGE, AUDIENCE, AND THE TRANSFORMATION OF DISPUTES
}

\author{
LYNN MATHER* \\ BARBARA YNGVESSON
}

\begin{abstract}
This article develops an analytic framework for comparing dispute processing within a single institution and across different cultures, by focusing on the transformation of disputes. Case studies from diverse nonwestern and western settings are examined to show how disputes change as they are processed in response to the interests of various participants. Disputants, supporters, third parties, and relevant publics seek to rephrase and thus transform a dispute by imposing established categories for classifying events and relationships (narrowing), or by developing a framework which challenges established categories (expansion). Disputes may be expanded by adding new issues, by enlarging the arena of discussion, or by increasing the number and type of active participants. Thus, how the dispute is defined (language) and the roles played by various participants are critical features of the dispute. We focus on the agent of transformation, with special attention to the degree of audience participation, particularly in dispute expansion. We suggest the importance of expansion as a mechanism through which new rules emerge in the legal process, and through which social change is linked to legal change.
\end{abstract}

\section{INTRODUCTION}

Our aim in this paper is to suggest the usefulness of the concept "transformation of a dispute" in (1) improving our understanding of how people manage processes of disputing and (2) showing how law and other normative frameworks are articulated, imposed, circumvented, and created as people negotiate social order in their transactions with one another. We draw upon case studies of dispute processing in a variety of

* Contributions of authors equal; name ordering alphabetical. This research was prepared under Grant Number 78 NI-AX-0138 from the National Institute of Law Enforcement and Criminal Justice, Law Enforcement Assistance Administration, U.S. Department of Justice. Points of view or opinions stated in this paper are those of the authors and do not necessarily represent the official position or policies of the U.S. Department of Justice.

An earlier version of this paper, "Triads and the Transformation of Conflict," was presented at the Law and Society Association annual meeting, May 10-12, 1979, San Francisco, California. Since that presentation, the paper has been revised several times. A number of people provided us with helpful comments and criticism based on their reading of earlier drafts. We are especially grateful to Hoyt Alverson, Henry Ehrmann, David Engel, Joel Grossman, Milton Heumann, Jack Katz, Sally Merry, and Stuart Scheingold. 
social, political, and economic settings and move toward developing an analytic framework for comparing cases both within a single dispute-processing institution and across different cultures. This framework should facilitate the comparison of disputes processed in institutional settings as widely different as courts, gossip networks, and broadly inclusive community arenas. Further, this framework will suggest how the processing of individual disputes is linked to larger considerations of social and political order. Specifically, we are interested in the relation between the definition and transformation of disputes, on the one hand, and the maintenance and change of legal and other normative systems, on the other.

By dispute we mean a particular stage of a social relationship in which conflict between two parties (individuals or groups) is asserted publicly-that is, before a third party (see Gulliver, 1969: 14; Abel, 1973: 226-227; Nader and Todd, 1978: 14-15). The third party may have an explicit role with respect to handling the dispute, as does the mediator, go-between, or judge; or act as an implicit third party, as do other parties such as supporters or an audience. ${ }^{1}$ The dispute stage can be distinguished from the grievance stage (of perception by one party of a wrong or injustice) and the stage of dyadic confrontation between the two parties (Nader and Todd, 1978: 14-15). One thinks of a grievance escalating into a dyadic confrontation, which then develops into a dispute; but in fact these stages of a disagreement are not necessarily sequential, and not every conflict goes through each stage. In addition, the grievance as initially perceived by one party may not be the object of the dispute once the matter is aired in public.

An assumption fundamental to our approach is that a dispute is not a static event which simply "happens," but that the structure of disputes, quarrels, and offenses includes changes or transformations over time. Transformations occur because participants in the disputing process have different interests in and perspectives on the dispute; participants assert these interests and perspectives in the very process of defining and shaping the object of the dispute. What a dispute is about, whether it is even a dispute or not, and whether it is properly a

1 Eisenberg (1976: 662-663), for example, suggests that supporters play an implicit third-party role: "negotiations conducted jointly by an actor and his alles on an institutionalized basis tend to slide imperceptibly into adjudication by the allies. Thus in Arusha dispute-settlement mechanisms, affiliates may put considerable pressure upon the disputants to go along with a settlement they judge appropriate" (emphasis ours). 
"legal" dispute, may be central issues for negotiation in the disputing process, ${ }^{2}$

By transformation of a dispute we mean a change in its form or content as a result of the interaction and involvement of other participants in the dispute process. Transformation is continuous, beginning when one party initially perceives a grievance against another. But in this paper we do not consider those changes involved in the early definition and emergence of conflict. ${ }^{3}$ Instead we focus on transformation after the conflict has been brought to a third party. Note that changes in the content of a dispute may not be distinguishable from changes in the form, since the inclusion or exclusion of certain facts or issues affects the way options are articulated and solutions are perceived (Barkun, 1968: 143; Levi, 1949).

At a fundamental level, the transformation of a dispute involves a process of rephrasing-that is, some kind of reformulation into a public discourse. Even the most rudimentary forms of disputing, such as public shouting matches which largely involve repetition and reiteration of the charges (Koch, 1974: 70, 104-105), include some form of rephrasing as the dispute proceeds; Eskimo song duels involve sophisticated forms of rephrasing (Hoebel, 1954); and nonverbal disputing such as chest-pounding, side-slapping, club fights (Chagnon, 1968: 118) can also be conceptualized as a way of reformulating a dispute to facilitate settlement and avoid breakdown of relations. In these examples, an audience or group of supporters acts implicitly as the third party to the dispute. As the role of the third party becomes more explicit, then the rephrasing is likely to reflect a greater, or more substantive, shift in the definition of the dispute.

Collier (1973), for example, describes transformation of disputes among the Zinacantan Indians of Mexico. She describes how litigants each present their own version of the "facts" to a mediator, knowing which outcomes are likely to result from which facts; then "the mediator's task is to rephrase the different accounts until the litigants agree on a single version of the events-a version that to the outsider might be puzzlingly skewed from reality" (Collier, 1973: 96). This "skewed" version of the dispute may continue to reflect

2 See especially Santos (1977), Strauss (1978), and Rosett and Cressey (1976). This perspective emerges as well in each of our earlier works (see Mather, 1977; 1978; Yngvesson, 1976; 1978).

3 For recent exploration of these aspects of transformation, see Felstiner et al. (1981); FitzGerald, Hickman, and Dickins (1980); Boyum (1980). 
the interests of either or both of the disputants, but it will most certainly also reflect the interests of the third party. Shapiro (1975: 325) argues that even the most informal kind of third party, such as a go-between, nevertheless "exerts influence by 'rephrasing' the message he delivers." Yet a skillful third party will accomplish this without appearing to force a value choice; rather, he will construe the facts in such a way that norms seem to relate to them inevitably (Barkun, 1968: 147). This is the essence of the rephrasing process. It presents a formulation which disputants and others might accept, and at the same time satisfies the interests of a third party. The interests of the third party in the dispute process may be of several kinds, as delineated by Santos (1977: 19): "personal interests . . . the interests inherent in the role he performs and the interests of the audiences to whom he looks for rewards" (see also Shapiro, 1975: 327).

Narrowing is the process through which established categories for classifying events and relationships are imposed on an event or series of events, defining the subject matter of a dispute in ways which make it amenable to conventional management procedures. Narrowing is the most common process of dispute transformation, and is particularly marked when a dispute is handled by officials of a specialized tribunal, such as a court, with highly routinized ways of handling cases. By "established" categories of the narrowing process we mean those categories which are linked to interests of the third party hearing the dispute. Third parties are often part of the local establishment. Typically then, one could say that (1) established categories at an initial dispute hearing will be those which are valid for a local elite; (2) there may be different categories for narrowing, even at the local level, and more than one may have legitimacy; (3) an established category in the local culture may or may not coincide with the "official" legal category; and (4) what is established at one legal level may not be established for another (see Collier, 1973; cf. Pospisil, 1958). Note that narrowing in this sense means fixing or circumscribing a framework in which the dispute is defined, rather than simply reducing or limiting the number of issues. ${ }^{4}$

Expansion, in contrast, refers to a rephrasing in terms of a framework not previously accepted by the third party. Expansion challenges established categories for classifying

4 The narrowing and expanding of issues is discussed, for example, by Ulmer (1979) in the context of Supreme Court decision making. See also Abel (1973) and Santos (1977). 
events and relationships by linking subjects or issues that are typically separated, thus "stretching" or changing accepted frameworks for organizing reality. Expansion does not necessarily imply the increase or magnification of issues in a dispute (although this may occur); it refers to change or development in the normative framework used to interpret the dispute. There is no neat line which clearly distinguishes narrowing from expansion, but there does seem to be something rather special about transformations which try to change the perspective through which disputes are commonly perceived. Thus we will focus on expansion with a view to identifying the strategies associated with expansion, the implications of expanded disputes for legal change, and the conditions under which disputes can be expanded.

We argue here that the expansion of individual disputes is one way that social change is linked to legal change. This point and our emphasis on changes in the framework of argument are, of course, classic themes in the study of the judicial process, as presented, for example, in Levi's (1949) $A n$ Introduction to Legal Reasoning and in Gluckman's (1955) The Judicial Process Among the Barotse of Northern Rhodesia. The legal process, says Levi, is not "the application of known rules to diverse facts," but rather a system of rules which are discovered in the process of determining similarity or difference between cases; "the finding of similarity or difference is the key step in the legal process" (1949: 3, 2). What determines that key step? Levi says that litigants and their lawyers must present competing examples or analogies to the court, and the judge will then choose the determining classification (1949: 2-5).

Gluckman's analysis of legal reasoning of the Lozi judges also focuses heavily on the role of the judge in "discovering" rules and in changing, while simultaneously maintaining, the legal framework. Gluckman provides numerous examples to show how Lozi judges, through the process of legal reasoning and case-by-case decision making, "have redefined their basic concepts to accommodate new facts of life" (1955: 325). He argues that this process of redefinition is accomplished in a gradual way because Lozi legal and moral concepts are highly flexible and ambiguous, and thus easily expand to incorporate changing social and political conditions. While the general concepts are being changed (with new meaning assigned by the judges), the labels remain the same (Gluckman, 1955: 324325). Thus both Levi and Gluckman employ judicial reasoning 
as a vehicle for explaining the "key step" through which new rules emerge in the legal process. Recent research in several bodies of literature has demonstrated the complexity of that key step, however, and has pointed to the critical role of participants other than the judge in shaping the process of legal change.

The framework we are advancing is an attempt to integrate analyses of legal reasoning such as those of Levi and Gluckman with ideas and findings from dispute processing literatures which focus more heavily on the social and political context of the legal process. We examine studies of lawyers and the mobilization of law, of trial courts and the judicial process, and of mediation, gossip, and other mechanisms discussed in the cross-cultural literature. Thus, we consider the differing abilities of litigants to argue their cases; the role of lawyers in shaping the way disputes are defined and presented; the influence of various publics or audiences with an interest in the definition and outcome of a particular case; and the complex relationships and informal norms which develop among groups of persons who cooperate in processing cases, whether in a trial court, a gossip network, or an open community arena. These factors must be integrated with empirical theory about legal order and change through reasoning by example. In addition, it is important that theory incorporate our knowledge of dispute processing and normative change in diverse sociocultural settings, both western and nonwestern.

Examination of these various literatures suggests the particular importance of three variables shaping the transformation of disputes: language, participants, and audience.

\section{Language}

The definition of a dispute articulated by each participant is a social construct which orders "facts" and invokes "norms" in particular ways-ways that reflect the personal interest or values of the participant, or that anticipate the definitions offered by others. These definitions of a dispute are similar to the "paradigms of argument" developed by Comaroff and Roberts (1977). In their discussion of Tswana dispute settlement, they suggest that disputants construct a "paradigm of argument" which is "a coherent picture of relevant events and actions in terms of one or more (implicit or explicit) normative referents" (Roberts, 1977: 86, italics omitted). Case materials suggest that an important feature of disputing in all 
social contexts (including those lacking written legal codes) is a struggle over these paradigms. How a relationship or dispute is phrased has significant implications for the power of competing individuals or factions with vested interests in the primacy of a particular framework.

Where there are written legal codes and an official language of disputing, language may become an even more critical variable shaping the disputing process. Under these circumstances, as Thompson (1975: 264-265) notes, the language of law must be reckoned with in its own terms: both rulers and ruled must explicitly deal with it as a point of reference in arguing cases and in legitimizing particular courses of action. Knowledge of "the law" and skill in manipulating its language become critical resources for defining and transforming disputes. We consider the language of disputing as varying along a continuum, with everyday discourse at one end and a highly specialized "language of law" at the other; we explore the effect of variation in language on the ways in which disputes are transformed, and on the roles of participants in the disputing process.

\section{Participants}

Although there has been a good deal of emphasis in the literature on dyadic versus triadic forms of disputing, case materials and recent theoretical work suggest that dispute negotiations are shaped by relations and transactions among a number of participants, not simply the disputants and a third party. We are specifically concerned with the roles of the disputants' supporters and representatives and by the relevant audience to the dispute. Participants (whether individuals or groups, whether disputants, supporters, or third parties) vary in terms of their power to shape the dispute and influence its outcome. Power is in part an attribute of the participants themselves, and in this sense participants will be distributed along a continuum of power in which degree of knowledge, experience, economic resources, or social standing will determine position.

It is clear, however, that power in the disputing process involves more than the attributes of individuals. It may depend, for example, on the relationship between the disputing parties and the legal forum. In organizationally complex arenas with a highly specialized language of law, as Galanter (1974) has argued, those who frequently engage in litigation (repeat players) are advantaged over those who only 
occasionally use the courts (one-shotters). In addition, power of participants may be influenced by the relationship of the disputing forum to the the broader society. If the disputing forum tends to exclude participation by other than the immediate parties or their representatives, then the power to transform a dispute in desired ways may be limited by lack of a relevant public or audience.

\section{Audience}

Understanding the role of the audience(s) in dispute processing is especially important in an analysis of transformation of disputes (see Santos, 1977: 18-20). Schattschneider (1960: 2) argues, "The spectators are an integral part of the situation, for, as likely as not, the audience determines the outcome of the fight." Carter (1979: 227) makes a similar point in discussing what judging entails: "To judge is to decide with reference to the expectations of an audience that defines the process of decision." This suggests how mobilization of a particular audience, either by the disputants or by a third party, might be a crucial strategy in the management of a dispute. Audience participation may vary from virtual exclusion of anyone but the participants to direct involvement by outsiders who physically watch the process, follow its progress, or verbally engage in the disputing discussions. Besides exploring the impact of audience participation, we also consider the conditions under which it is likely to occur and be influential. We draw on Edelman's (1964; $1971 ; 1977)$ work in symbolic politics and political language to discuss processes through which audiences are mobilized and disputes expanded.

Focus on language, participants, and audience helps us to explain dispute transformations and the degree to which those transformations lead to particular case outcomes, and influence order maintenance and change. These variables are by no means exhaustive; furthermore, their precise interaction cannot be specified at the present time, since transformation processes are extremely complex. Our aim in this paper is to suggest ideas for building a theory of transformation of disputes; as yet no theory enables us to predict how a given dispute is likely to be transformed. 


\section{NARROWING}

To fix the object of a dispute is to narrow it. That is exactly what the legal process does in defining what is to be decided. This selection is determined by the needs and purposes of the legal process (Santos, 1977: 18).

Most disputes are transformed through some kind of narrowing - that is, through the use of established categories to organize the events and issues in dispute. Typically one thinks of narrowing in highly differentiated legal arenas where specialized legal discourse is used to transform disputes in prescribed ways. But the process is a fundamental aspect of disputing, occurring in contexts as widely diverse as the "house palavers" of the Kpelle (Gibbs, 1963), the public shouting matches and scuffles of the Jale (Koch, 1974), and the gossip networks of North Atlantic villages (Peters, 1972; Yngvesson, 1976). In these settings, as in specialized forums, participants argue about which definition should be imposed on the events and relationships in a dispute; the question of which definition will be used is of considerable significance to the outcome. Whether the discourse is specialized or more general, disputes will be narrowed in ways acceptable to a third party (either to appeal to the third party or inflicted by the third party). This introduces interests beyond those of the disputants into the dispute at hand; most likely these additional interests will reflect power of the third or political interests of those connected to the third. In this way rephrasing of disputes into established categories merges with the conflict-resolving and social control activities of the third party (see Shapiro, 1975).

In presenting the following cases to illustrate narrowing, we are especially interested in how language (or "conceptual space"), as well as physical space, influences dispute transformations and defines the roles of participants in the disputing process. Thus the central foci of our discussion will be the language of disputing and interrelationships between shifts in language, changes in the roles of participants, definitions of the events in a particular dispute, dispute outcomes, and broader patterns of social organization.

\section{Narrowing Through General Discourse}

Some changes in the definition of a dispute are deceptively simple: e.g., a dispute over complex issues is translated into the terms of a currency (money, pigs, land, cattle) which allows the issues in dispute to be quantified. Thus Collier (1973: 169), showing how kin disputes among the Zinacantan Indians of Mexico are rephrased as property disputes, notes that 
"Zinacantecos, like many peoples, reduce ... complex, subjective problems . . . to straightforward disagreements over something tangible, something that can be objectively measured and divided." Tort actions under common law epitomize this kind of transformation of disputes over injuries into disputes over money. For instance, Rosenthal's (1974) study illustrates how a personal injury plaintiff describes an accident to his lawyer in terms of a broad range of medical, emotional, family, work-related, and other concerns; the lawyer then rephrases the account in terms of a dollars-and-cents description of the case. Translation into the terms of a currency, such as money or, as in the first case below, pigs, converts the complex into the straightforward; significantly, however, it also reinforces the dominance of a particular currency as the standard through which people, products, and other resources are made commensurable. ${ }^{5}$

The case of the Stubborn Gardener is drawn from Koch's (1974) ethnography of the Jale, a people in highland New Guinea who lack institutionalized leaders and whose political organization is based on lineage descent and affiliation. Although the Jale lack formal legal institutions, disputes are managed in predictable ways, in the framework of agreed-upon idioms for articulating and transforming conflict. The Jale's major idiom for rephrasing is provided by their primary trade item, pigs. Koch writes that "every pig is a potential vehicle for the validation and reaffirmation of social relationships. All major events in a person's life cycle, the settlement of serious disputes, and the ratification of peace agreements require the transfer of pigs" (1974: 42). Significantly, means for the successful use of this idiom are controlled by Jale "big men," individuals whose managerial finesse and verbal skills have resulted in extensive debt networks and superior solvency as pig owners and brokers (Koch, 1974: 63-65). Rephrasing of individual disputes in the language of rights and obligations with regard to pigs thus strengthens both the value of that currency and the dominating role of the "big men" who control it.

5 Bohannan (1971: 257) discusses the function of general-purpose money as providing a "common denominator" among several separate exchange spheres, thus making commodities in each immediately exchangeable. (See also Bohannan and Dalton, 1970: 230; Polanyi, 1957: 264-266.) Bohannan also discusses the implications of this standardization for the value of the commodities themselves. For example, receiving and giving money in order to acquire, or in exchange for, women has acted to devalue the exchange and the institution of bridewealth marriage (1971: 259). 
This case (Koch, 1974: 125-127) involves Selelemangke and Herin, two men from neighboring wards in the same village. They were clearing brushwood on contiguous garden plots when Selelemangke claimed that Herin was trespassing on his garden land. The next day, Herin came to the site with two dozen men and boys from his ward; Selelemangke, likewise, was accompanied by his supporters. A shouting match between the groups developed into a scuffle, but disapproving shouts from the older men present halted the fighting. Koch notes that the dispute over land stemmed from an earlier dispute over Selelemangke's failure to reciprocate the gift of a pig he had received from the brother of Herin's wife. Beyond this, there was an implicit grievance which arose out of a recent inter-village war in which Herin's ward had been involved. Selelemangke's son had fought in the war, against Herin's ward, even though the two wards were traditionally allies. ${ }^{6}$ As the dispute proceeded, the two groups continued to shout at one another, and Koch (1974: 126) writes, they "warned of the deplorable consequences their fight would have in the face of the unsettled conflict with their common enemies." In an effort to settle the dispute, Herin chose to define the major issues in terms of the pig debt and offered to leave the land to Selelemangke if the latter delivered a pig to Herin's brother-inlaw. This was not satisfactory to Selelemangke, however. A compromise was finally reached when Herin agreed to cultivate the land he had cleared (which presumably included some of Selelemangke's property) for one season only, and Selelemangke withdrew his claim (perhaps influenced by some recognition of the unpaid pig debt).

There was no mediator or explicit third party handling this dispute, but the supporters of both men played an implicit third-party role in urging the disputants to compromise. Midway through the dispute, several supporters discovered remnants of an old stone wall marking a boundary between the two pieces of land. The actions of the supporters in finding the common boundary, and in pressing for the need to present a united front to their common enemies, encouraged the two disputants to rephrase their dispute in terms acceptable to both. Note that Selelemangke had initially formulated the dispute in terms of land rights, while Herin had defined the issue in terms of pig transactions. The rephrasing suggested by

6 Note that Herin might have chosen to trespass on Selelemangke's land simply in order to air these underlying grievances in public, although Koch does not discuss this possibility. 
the supporters served also to shift slightly the definition of the dispute to include the relations between the two wards and the enemy village. That is, the broader interests of an audience to which both men were closely linked altered the framework for seeing the dispute by placing it in the context of alliances and village security.

The next case, from a Chagga community in Tanzania, also shows active audience participation in negotiating and defining the object of the dispute, but the balance of power in this community is much less even than among the Jale. The Chagga are more heterogeneous than the Jale; once a homogeneous community of farmers dominated by local kinship organization, the Chagga now also have a small but influential group of educated, white-collar, salaried men who work in nearby towns. The developing ties of social class cut across lineage loyalties, Moore suggests (1977: 174), and affect the choice of framework for conceptualizing issues in a dispute. In the case below, one of the frameworks (that of individual rights to land) clearly gained precedence over the other, more traditional framework (that of the rights and obligations of kinsmen to one another). Pressure to use this former framework was created by an alliance between the third party in the case (the ten-house leader) and the public of whitecollar, salaried men of which one of the disputants was a part.

The Uprooted Seedlings Dispute (Moore, 1977: 161-187) involves two Chagga lineage brothers in Tanzania in a quarrel over seedlings planted along the common boundary of their coffee-banana groves. The case was brought by Elifatio, the elder and poorer of the two men, against Richard, a prosperous young clerk, for uprooting seedlings Elifatio had planted along the common border of their land. The dispute was heard by a small gathering of kinsmen and a few neighbors, one of whom was leader of the imposed local government unit, a "ten-house cell." Richard argued that he had not uprooted Elifatio's seedings, since the seedlings had been planted, not on Elifatio's land, but on a village (government-maintained) path which ran through Richard's own land. Thus Richard's argument shifted the substance of the dispute to the question of the boundary between the pieces of land, and to a discussion of whose land the path cut across. One of the senior men present then suggested moving to the site of the uprooted trees to hear Elifatio's wife and son say that they had seen Richard pull up the seedlings. Others agreed with this suggestion, since it would also allow examination of the path and boundary in 
question. Negotiation over the two conflicting definitions of the dispute continued as the entire group actually moved to the area where the plants had been.

As the discussion proceeded, the size of the group increased with the addition of kinsmen and neighbors and several white-collar workers who were daily drinking companions of Richard. Elifatio's kin tried to focus the dispute on the alleged wrong caused by Richard's actions: "He had no business taking matters into his own hands and doing the uprooting himself" (Moore, 1977: 170). But supporters of Richard dominated the argument, and Richard himself succeeded in defining the normative framework through his presentation of the facts: "I don't know who planted the trees I uprooted. I uprooted them after I saw that they were planted in the land of the Government" (Moore, 1977: 168). Various aspects of these issues emerged during the several hours of talk. When a lineage elder called for a compromise agreement to settle the matter, the ten-house leader openly opposed him, asserting the need for an either/or decision in the case. The ten-house leader then pronounced Richard in the right, based on a judgment about the boundary issue and ignoring the selfhelp issue.

Richard's success in part seems related to his ability to work out a strategy of presentation and his facility in clearly articulating his case. Beyond this, however, Moore points to the vocal and prestigious roles of both Richard's kin and his educated, salaried friends; and she notes the importance of connections between these salaried men and the ten-house leader who decided the case. The village hearing thus provided "an opportunity for certain public collectivities to come into competitive contact, to act authoritatively, to demonstrate and to reaffirm local relationships of superordination and subordination" (Moore, 1977: 177). The public which provided Richard's point of orientation and support-white-collar workers employed in the towns (and not their "impecunious farmer brothers" [Moore, 1977: 177] in the village)—became the crucial audience for the Chagga leader who presided at this hearing. ${ }^{7}$ Had the common audience of lineage kinsmen taken precedence (as in the Jale case), then the emphasis might have

7 This may slightly oversimply the dynamics of the hearing, since Moore notes that the strength and prestige of the lineage seniors were also more on Richard's side than on Elifatio's (1977: 176). Thus Richard had support from both the white-collar workers and important lineage elders. Traditionally, the elders would have sought a compromise decision in the case (and did so unsuccessfully in this dispute). The ten-house leader, however, as spokesman for a new, imposed legal system, advocated an either/or decision and thus was 
been on a mutually acceptable rephrasing. Instead, however, the salaried men dominated the audience and influenced the outcome of the dispute. ${ }^{8}$ Thus we find in nascent form the processes which are so marked in bureaucratized court contexts and which are well illustrated in the next phase of this dispute: narrowing of the dispute in accordance with the categories and interests of a particular public which may or may not share the interests of either of the disputants; and an outcome, defined by this rephrasing, which is advantageous to the public or group which imposes its classification system on the dispute.

\section{Narrowing Through Specialized Legal Discourse}

In the second phase of the Uprooted Seedlings Dispute, Elifatio appealed the neighborhood ruling to a Primary Court on Mt. Kilimanjaro, the lowest court in the national judicial system in Tanzania. Since civil litigation would have cost a filing fee, Elifatio followed the court clerk's advice and filed a criminal complaint for malicious destruction of property, and his case was heard a week later. Elifatio had no witnesses, and Richard denied the charge that he had uprooted Elifatio's seedlings. An effort by one of the court assessors to introduce the relationship of the two men as a factor to be considered in the case failed when the Magistrate ruled that the information was irrelevant. The questions which had dominated the village proceeding -on whose property the seedlings were planted, and about the nature of the path-were not raised, and Elifatio lost his case. The general legal category of "malicious destruction of property" helped to define the normative framework for the dispute in the court hearing. Moore notes that, "once the issues are narrowed in this way, there is no need to inquire into the general situation, the background, the relationships of the parties, the motives, and the like" (1977: 182-183). Further, the local publics shaped the case at both the village and court levels. The individuals and the ten-house leader who supported Richard influenced the definition of the case at the neighborhood hearing; and by refusing to act as

particularly attentive to the support provided by white-collar workers in the audience.

8 The ten-house leader especially needed good contacts with the salaried men to help with his unofficial and official duties. For example, when collecting the necessary funds for the TANU party, the ten-house leader counted on the salaried men's cooperation, since they were more likely than the farmers to have the cash available to contribute (Moore, 1977: 176-177). 
witnesses in court, they assured a definition and outcome in Richard's favor (Moore, 1977: 186). ${ }^{9}$

In the Tanzanian court, a specialized legal discourse restricted the alternative frameworks available for defining events and relationships in the dispute. Here, and in the next two cases, there is one official legal language controlled by court officials or by legal specialists; proper rephrasing of a dispute in this language is essential if the dispute is to be dealt with in an official disputing forum. These forums are clearly set apart from the everyday contexts in which disputes arise and thus facilitate the imposition of an official legal idiom for disputing. To the extent, however, that the forums continue to maintain close links to a relevant public beyond the boundaries of the forum itself, the disputing idiom reinforces patterns of social order advantageous to certain community groups and less favorable to others.

The Ox Cart Dispute in a Thai provincial court was recorded by Engel (1978: 120-124). It illustrates particularly. well the use and implications of alternate idioms for phrasing events and relationships. The official idiom for disputing in Thailand, or what Engel terms the "language of law," derives from a legal code modeled on western systems of justice and introduced in Thailand at the turn of the century. As Engel notes, "The new Thai law codes, both explicitly and implicitly, articulated a new and radically different view of the private citizen, the family, the social group, the administrative bureaucracy, and the nation as a whole" (1978: 2-3). Most private litigants in Thailand avoid phrasing their disputes in this idiom, however, preferring traditional frameworks for defining and handling conflict. These frameworks stress not the rights of private citizens, but the obligations of status superiors (men, fathers, husbands, patrons, etc.) to assume responsibility for their dependents or clients. Nevertheless, some individuals do attempt to pursue traditional goals in court, using the official language, as in the following case.

In this case, the new legal code transformed a dispute between two men, regarding cash payments of damages for the death of the son of one of the men, into a lawsuit between the wife of one and the daughter of the other. The case developed

9 Moore (1977: 186) describes both of these proceedings of dispute settlement as "ceremonies of situational transformation ... [that] turned Elifatio's private quarrel into a public ruling." Our usage of the concept, transformation, differs from hers in that we are talking about transformations of the framework of argument of the dispute as it proceeds, rather than transformations of "a dispute between two parties into a declaration by a third" (Moore, 1975: 112). 
when the 16-year-old daughter of one man accidentally killed the son of the other when the wheels of the ox cart she was driving struck the boy. According to customary procedure, the father was liable for his daughter's acts, and the father of the dead child was the person to whom compensation was owed. Both men initially agreed on the terms of compensation (payment of the funeral expense) within this traditional framework, but the dead child's father subsequently decided to pursue the matter further in court to obtain additional cash payment for his son's death. This required that the dispute be rephrased, since legally he was not considered the proper representative for his son (his marriage to his common-law wife of twelve years had not been officially registered) and since, legally, it was the 16 -year-old girl, and not her father, who was considered responsible for the act of negligence.

Engel writes that "the code procedure appears on the face of it to have changed the dispute entirely. Instead of being a conflict between [the two men], the code transforms the dispute into a lawsuit involving [the wife of one and the daughter of the other]. Except for the formalistic changes, however, the procedural requirements of the law codes do not really alter the goals of the disputants at all. The ultimate purpose of the plaintiff is still to receive compensation from [the father of the 16-year-old girl], just as it was from the beginning" (1978: 123). Engel emphasizes that "the law codes change the form but not the substance of the dispute. The traditional goal of compensation is pursued by manipulation of the Penal Code. The traditional concepts of standing and liability are also retained implicitly, despite the fact that figurehead plaintiffs and defendants must be substituted for their traditional counterparts in the process of litigation" (1978: 123-124).

While Engel's analysis of this case is quite correct, we would point to an aspect of the case not emphasized in his book: the implications, both for the litigants and for broader patterns of social organization, of moving to a specialized legal discourse. Significantly, the original plaintiff (the father of the dead child) did not succeed in rephrasing his claim in the manner described above. He had filed a private criminal suit against the 16-year-old girl; this action managed to properly assign liability under the law code, but it did not fit the legal requirement of standing. The judge acquitted the defendant, holding that the plaintiff "had no standing to bring a criminal action ... on behalf of the deceased, because his marriage to 
the boy's mother had never been lawfully registered" (Engel, 1978: 121). In ruling against the plaintiff, the court skillfully responded to two publics with competing interests in this case. It implicitly rejected the traditional concept of standing in favor of one linked to the officially defined concept of marriage, and in this way reinforced a normative order decreed by the new Thai code. At the same time, by acquitting the defendant, the court reinforced the values and balance of power upheld in traditional settlement procedures. ${ }^{10}$

The outcome of the Ox Cart Dispute illustrates both the necessity of changing definitions of a dispute in order to make it amenable to legal action and the critical level of skill and knowledge required to manipulate definitions, for particular ends, when specialized language and arenas are involved. That the required transformation in this case was, in a sense, procedural, should not obscure its substantive importance. A certain degree of political bias is built into the disputing process simply through the official legal language, since this limits one's role in a case as litigant or as relevant witness according to the specialized definitions provided by that language. ${ }^{11}$ Even further, the need to rephrase a dispute into the official language of law restricts the disputing arena to those who can understand and use the language or who can hire someone to act on their behalf.

The Lost Negatives Dispute is taken from Cain's (1979: 340341) research on solicitors in England, and illustrates the role of lawyers in modifying disputes so that their client's needs, as well as the requirements of the legal system, are met. Cain writes that "clients bring many issues to the solicitor, expressed and constituted in terms of a variety of everyday discourses. The lawyer translates these, and reconstitutes the issues in terms of a legal discourse which has trans-situational applicability. In this sense law is a meta-language" (1979: 335).

10 We are indebted to David Engel (personal communication) for pointing out this aspect of the case.

11 The California case of Marvin v. Marvin (1976) provides an interesting parallel to the Thai Ox Cart dispute and underscores the substantive import of definitions of persons in legal discourse. When Michele Marvin first sued Lee Marvin for property rights upon the break-up of their relationship, the trial court threw out the case on the ground that their unmarried living arrangement implied a "meretricious" or sex-for-pay relationship. The landmark decision of the California Supreme Court in 1976 to overturn the trial court was actually just a procedural ruling that allowed the case to proceed to trial; the Court held that unmarried persons are not barred from litigation over property even though they had shared a bed. By simply allowing Michele Marvin to act as plaintiff in her lawsuit (a procedural issue), the California Supreme Court significantly altered the normative definition of the rights of unmarried women in live-in relationships. 
Cain provides a clear example of translation in a case involving some lost photographic negatives of a royal family. The plaintiff was the original owner of the negatives; he gave the negatives to a woman's magazine who apparently loaned them to Smith, a director of a film company. Smith had since left the company "under a cloud," and the plaintiff was suing the company for $£ 10,000$ for the lost negatives.

Lawyer A (observed by Cain) represented the film company itself (with its remaining two directors). Lawyer A argued successfully before a court of appeal that "the company had not been formed until three days after the photographs had been given to Smith. ... The company could not be responsible for them as it was not in existence at the time. The correct procedure would be to bring a case against Smith in person and to join the woman's magazine in the action" (Cain, 1979: 340). Lawyer A thus achieved his client's outcome by "juggling the translation of people into directors.... The situation here was that in everyday discourse they [the remaining two directors] were not responsible, and had had nothing to do with the issue. They were being challenged, however, in terms of a legal discourse of liability, which had to be refuted in its own terms" (Cain, 1979: 341).

The $O x$ Cart and Lost Negatives disputes were both shaped in significant ways by the existence of a written legal code: an official, public discourse by which specific definitions of roles and relationships were legitimated. Successful management of these disputes required not simply persuasive power or a broader array of supporters, but skill in manipulating the discourse. Important questions in cases such as these, then, include: who controls the use of legal (or other official) language, who has access to the language (or to those who are skilled in using it), and to what extent is the language used responsive to the needs of disputants? Edelman suggests that "the laws create a space in which to act" (1964: 103), but one must ask "whose space" and "who is able to act in that space?" In both the preceding cases, involvement of a specialist in legal discourse was necessary to successful management of the dispute. The specialist may serve as a kind of "culture broker," translating the concerns of a disputant into the language of law; or, as Cain (1979) suggests, the specialist may impose his own concerns in defining the case. ${ }^{12}$

12 Cain (1979) distinguishes between a lawyer's role as a translator and his role as a transformer. The lawyer translates issues expressed in the language of everyday discourse, into the terms of legal discourse (1979: 335 ). In 
Participation by legal specialists thus interjects another set of interests in the phrasing of a dispute. These interests may reflect, for example, the specialist's (whether lawyer or judge) own financial concerns, relations with colleagues on the bench or at the bar, or his own political attitudes as to goals or interests to be pursued through a particular case. The official legal language prescribes the general frameworks and definitions to be used in classifying events in a dispute, but the actual use of those categories will depend upon the intermediary legal specialists. In situations where the intermediaries and legal officials work regularly together over a period of time, they may develop their own operational meanings of the legal codes and follow their own informal procedures for processing cases. Rephrasing of disputes may then emphasize issues relevant to the informal norms and local working environment of the legal forum, rather than to the broader community or the legislative officials. Plea negotiations by criminal court regulars in American courts clearly illustrate this narrowing according to "folk legal categories"-categories which are developed by actors within the court as they process cases.

Criminal court research has shown how statutorily defined categories of crime are modified by the subculture of justice in local courts to produce the working definitions of "normal crime" and "real" criminals used by court personnel. These working definitions shape plea bargaining as well as other discretionary decisions in the criminal courts (Sudnow, 1965; Rosett and Cressey, 1976; Mather, 1979). They are the product of repeated interaction among the same court personnel as they routinely process cases, and they are shaped by the range of deviance with which court personnel are presented on a daily basis. Emerson (1969: 84), writing specifically about juvenile court processes, explains one consequence of this repeated handling of deviance: "Routinely encountering a wide range of youthful misconduct, the court develops a relatively narrow definition of delinquency. This definition generally requires quite frequent and serious manifestations of disturbing conduct before a youth will be categorized as 'really delinquent." "Similarly, the categorization of cases within the adult criminal court generally suggests a higher tolerance for deviance than that found in society at large. This contributes to specialized distinctions between levels of crimes. Thus, for

contrast, lawyers may transform the objectives desired by the client into others which seem more reasonable from the lawyer's perspective (1979: 347 ). 
example, behavior that may correspond legally to first-degree robbery will not be so labeled in plea negotiations because it is not "really" first-degree robbery in the eyes of the court.

The case of the Drunken Burglar (Mather, 1979: 97-98) is drawn from research on plea bargaining in Los Angeles Superior Court, and it illustrates negotiations over the narrowing of a burglary case. The defendant had five prior burglary convictions. As the Public Defender described the case, "The guy was caught drilling a hole in the wall next to a safe in a store. There's no defense at all" (Mather, 1979: 97). There was also evidence that the defendant had been drinking just before his arrest, and the Public Defender felt that "the guy's just an old drunk" (Mather, 1979: 97). Bargaining over the disposition of this case centered on evaluation of the defendant's character. Based on his view of the defendant, the defense attorney tried to arrange a county jail sentence through a transfer to a particularly lenient judge, but the prosecutor would not agree. The defense attorney stated, "He figured with five priors and drilling a hole in the wall by the safe that the guy's not just an old drunk. That he's a professional burglar. I don't think so, though" (Mather, 1979: 97). Thus the prosecutor insisted on a commitment to state prison based on his classification of the defendant. Finally, however, the case was transferred and the defendant pled guilty with no sentence agreement. There were two presentence investigations done on the defendant, and although both reports were unfavorable, the defense attorney had succeeded in delaying the case enough to win a lengthy county jail sentence. The judge sentenced the defendant to one year (the maximum possible) county jail with no credit for time served (which was by then about nine months).

Whether the attorneys agree on application of their folk legal categories, or whether they do not (as in the case above), it is significant to note that their classifications are determined with little direct participation from either the defendant or the victim in the dispute. Working definitions of cases in the criminal court reflect the attitudes and experience of the court regulars and the ongoing relationships among them, as well as the organizational priorities and demands of the court in terms of, for example, its limited personnel and resources. In this way, the narrowing processes of plea bargaining are often highly responsive to, and shaped by, the requirements and interests of the court itself. 
For example, attorneys in a criminal court evaluate the strength of evidence in a case according to their perceptions of local judge and jury behavior, rather than by textbook criteria on evidence. Attorneys in Los Angeles categorized cases as "dead bang" where there was a very high chance of conviction, while attorneys in Connecticut referred to these same cases as "born dead" (Mather, 1979; Heumann, 1978). Categories of "serious" and "nonserious" (or "light") are similarly used by criminal court participants to sort cases according to values and priorities within the court.

In some courts political struggles between factions within the court will influence the way a case is rephrased, as suggested by Yngvesson's (1978: 141-148) study of the implicit negotiations between criminal court personnel and the mental health professionals who staffed an urban court clinic. The clinic required a case load of a certain size to assure continued funding of its program, and clinic personnel were eager to establish the legitimacy of their (mental health) perspective on case definition in order to increase their control over a particular defendant population. The clinic thus sought to broaden the range and increase the number of cases they handled by controlling the category of seriousness by which cases were classified.

These examples of the folk categories in American criminal courts support Abel's (1973: 271) suggestion that as dispute institutions become more differentiated "the universe of substantive norms involved in the dispute process diverges from that employed by the society at large ... [and] the process increasingly develops norms peculiar to itself." This tendency is intensified as "the institution develops a carapace, impermeable to external information, prescription, or influence. Behavior grows introverted, preoccupied with its own norms and activities. The problems it handles are the problems defined by the institution, not the society; the solutions it generates are solutions for the institution, not the society. If carried to an extreme, the dispute process becomes wholly involuted, hermetical, the exclusive domain of specialists, and comprehensible to them alone" (Abel, 1973: 265). Legislatures have responded recently to the specialized subculture of the criminal courts by reducing the discretion of court officials through determinate sentencing, mandatory prison terms, and prohibitions on plea bargaining. In this way legislators hope to realign court norms along the lines of what they perceive to be broader societal norms (or rather, the norms of the relevant 
publics for legislators). Such attempts are likely to meet with only limited success, however, in part because of the great control over case definition and processing possessed by lawyers and court officials .(see, e.g., Heumann and Loftin, 1979).

\section{Summary}

The cases discussed here illustrate the importance of the process of narrowing disputes, the need to examine the alternative definitions available to litigants, and the linkage between these definitions and the broader political order. Translation of disputes into the terms of a particular discourse strengthens the position of those whose interests and values are represented in that discourse. For example, conceptualizing a dispute in terms of kin obligations instead of property rights (as in the Chagga dispute) reinforces kinship ties and maintains the power of kin elders.

The introduction of an official language of law increases the power of certain political interests by restricting access to the disputing forum, by defining the kinds of disputes which can be placed on the agenda of the forum (and therefore, restricting public discussions about disputes not so legitimated), and by defining the roles of the parties in very specialized ways (and thus affirming who is "relevant" to cases and who is not).

Thus, our discussion of narrowing illustrates various ways in which the disputes of individuals serve as vehicles through which others in society assert claims to power. Which others become central in this process may depend upon the form of discourse used and the barriers to involvement of broader publics in the disputing process.

1. Where the discourse is specialized, those who know the language will tend to control the disputing process; this control may be further reinforced by varying degrees of physical separation of the disputing forum from the society at large.

2. Where the discourse is specialized, disputants may have less access to and influence over the disputing process than do others such as translators and representatives of interested publics. Disputes will be transformed in accordance with the relative power of those within the disputing forum.

3. Under any form of discourse, playing to a broader public becomes important for disputants and third party alike and may be a particularly useful strategy for 
less advantaged litigants. In addition, highly active and organized publics may capture the dispute, bypassing litigant interests to press for outcomes in accord with their own interests.

4. Where the discourse is general, the disputing process is more accessible to both disputants and publics. Under these circumstances, interests of a broad public or particular groups will constrain the ways in which litigants, supporters, and third parties can transform a dispute.

5. The more general the language and the greater the degree of audience participation, the greater the possibility that the law can be shaped by, and will be responsive to, a more broadly defined community interest. The greater the degree of inequality in the society, however, the more likely it will be that particular interests will shape dispute transformations and legal norms.

\section{EXPANSION}

On the other hand, this tendency (from breadth to narrowness) is not irreversible; during the processing of disputes shifts of direction are frequent, which expand the inquiry into new areas. And the key to a deep understanding of the legal process lies in the explanation of this dialectic (Santos 1977: 18).

In this section we will consider dispute transformations in which an organizational framework not previously accepted by the third party is imposed on the events and relationships encompassed by the dispute. In some of the "narrowed" cases discussed in the last section, we pointed to a struggle between parties over how a dispute should be classified, and noted how the results of the struggles served to increase or weaken the power of particular factions at the local level. In the Uprooted Seedlings Dispute the nature of this struggle was particularly clear-cut, and we argued that the outcome of the dispute further consolidated the power of a new "established" group among the Chagga, one which seemed to be slowly gaining in prestige and influence.

The cases we will consider next provide other examples of struggles such as that between the Chagga farmers and town workers, but in these cases there is a more clearly defined established order. Narrowing the cases in terms of that order occurs at one stage of the disputing process, but at another stage-the one we will focus on here-the dispute is rephrased 
in a way that implicitly or explicitly challenges that order. The consequences of dispute expansion may be limited to the dispute itself, or they may involve broad legal or political change. For example, in some of the cases presented below, the outcome of expansion involves primarily a change within the dispute, and the implicit challenge to the broader normative order is not pursued (Headman's Fishdams, Deviant Mechanic). In others, the attempted rephrasing has little effect on the individual dispute (which serves as a vehicle for expansion), but may have greater impact on the way future cases develop (Underpaid Nurses, Thai Murder Case). Finally, in some cases the outcome of the dispute significantly changes the traditional folk system of classification and introduces new criteria for organizing future disputes (Incestuous Lovers, Mapp v. Ohio, Quadriplegic Father, Amish Dispute).

Explaining the outcome and consequences of expansion of a dispute is obviously difficult. Factors one should look at include: degree of dissatisfaction (both in intensity and scope) with the established order in society; extent to which those who are unhappy with the established order for reasons of their own would benefit from an ordering of issues along the lines suggested by the expansion; timing of emergence of a particular case in relation to other similar ones; particular constellation of facts and issues on the case itself; relation of redefinition to parallel political cleavages; and extent to which an audience becomes involved in the disputing process, giving credibility and support to the shift in perspectives on the dispute. Following Edelman's (1964) distinction between mass and organized publics, we note that a broad, diffuse, unorganized public may be content simply with a redefinition of the dispute at hand, while a smaller, more narrowly focused, organized public is more likely to pursue implications of the dispute expansion leading to fundamental changes.

In addition to our attention to the audience role in dispute expansion, we also emphasize the ways in which language is used as a vehicle for transformation. Edelman (1964: 131) noted that "the terms in which we name or speak of anything do more than designate it; they place it in a class of objects, thereby suggest with what it is to be judged and compared, and define the perspective from which it will be viewed and evaluated." To expand a dispute, in our terms, is to change the perspective from which the third party would ordinarily view the act, person, or relationship involved in the dispute by placing it in a class of objects from which it would normally be 
distinguished. This is a political process. Individuals and groups have vested interests in particular definitions of persons and events; changes in definition tend to meet with resistance, and thus require some basis of support if they are to succeed (e.g., linkage to a relevant public with some political or economic power). It is a linguistic process in that changes in perspective and definition involve applying new labels to familiar persons and events. These new labels act as "a catalyst in the shaping of perception. . . . [P] eople potentially see an issue in several alternative lights, and the language form itself evokes some of the potentialities" (Edelman, 1971: 68, emphasis added).

Both the political and the linguistic aspects of this process are shaped by the extent to which an audience directly participates in the dispute, as well as by the form of discourse in which the dispute is argued. We can contrast, for example, expansion through specialized discourse in a forum with no direct participation from a broader public with expansion through general discourse involving broad audience participation. In the first situation, control over case definition is held by those within the forum who may seek to redefine disputes by manipulating the categories of the official legal language. Disputes may then be expanded through a process of case-by-case reasoning in which the key feature is arguing the points of similarity and difference between one case and others (Levi, 1949). Linguistically, this involves focusing on those parts of otherwise different cases which can be seen as similar, and reasoning from them to the grounds for applying a similar classification (Levi, 1949). Politically, the decision to connect diverse facts in new ways must appeal to an identifiable supportive public beyond the bounds of the forum. Thus, lawyers and other supporters who take an active role in redefining disputes may translate the concerns of particular publics in the process of expanding an individual dispute. Similarly, when the third party rephrases a case with an implicit or explicit challenge to previous orderings, it will try to link the new definition to the interests of a particular constituency to which it feels itself (or wishes to be) responsible.

Expansion by a larger public, through the use of general discourse, involves a somewhat different process. The language of categorization is less constraining since there are no official labels to be manipulated, but the political problem of sustaining an expansion may be more difficult in this situation. 
Here the problem is not linking up to a particular group or set of interests which might justify a redefinition; rather, the problem is that of actually mobilizing a vocal public around a particular rephrasing of a case, so that a perspective which may be in conflict with that of the community's power structure acquires some legitimacy.

The arousal of such a public may occur through a highly visible, dramatic image or use of language based on an assumed set of shared meanings, with simple forms and incomplete exposition (Edelman, 1977). ${ }^{13}$ Interestingly, success in classifying an event or person in a particular way may often depend on masking, rather than clearly articulating, the premises on which the classification is based. This is especially important when large publics are involved. It can be accomplished by skillfully bringing into play familiar imagery which connects with and highlights one aspect of a person or situation, thus redefining the whole person or event in those terms. The use of familiar imagery (through photography or a dramatic public speech) to mobilize broad public support in favor of a redefinition of a case is strikingly evident in several of the cases we will discuss below. For example, in the Amish Dispute, a photograph of Amish children fleeing police and state officials acted as a vehicle for transforming the case by focusing attention on helpless children being chased by police. It shifted the framework in which the case was perceived from one of willful disobedience of the state code by the Amish, to one of persecution of the Amish by the state. Photographs or other aesthetic forms may play a dual political role; most commonly they reinforce conventional beliefs, but they can also "teach their audience to see new meanings . . . leading people to new insights and to perceptions of new possibilities" (Edelman, 1977: 107; see also Langer, 1946). If, in fact, art performs this dual function, it is surely a highly strategic means for subtly changing the way events and relationships are viewed, since traditional imagery can be used to graft new meanings onto old relationships, rather than simply to reinforce conventional beliefs.

Our discussion of dispute expansion is organized according to the agent of transformation (third party, supporters, audience). We will begin with cases in which audience participation is implied, but primarily as a point of reference

13 Edelman (1977), following Bernstein (1975), describes this form of language as "public language," in contrast to "formal language," which focuses more on logical relationships. 
for the agent of transformation, who in each case is a third party. We will move then to expansion by supporters, and finally to three cases in which the dispute is expanded by means of widespread public or audience participation in the disputing process.

\section{Third-Party Expansion}

In the case of the Headman's Fishdams (Gluckman, 1955: 178-191) a dispute between a village headman and his kin over their rights to use village land is converted by a judge into an administrative decision on the fitness of a headman to occupy his position. The dispute stemmed from claims by two sisters for their rights to use fishdams in their brother's (Mahalihali) village. Relations between the sisters and their father, the previous headman, had been poor, and both had left his village. However, the sisters had continued to fish there in spite of the Lozi law that only residents of a village are entitled to use village land. In exchange for use of the dams, one of the sisters had sent her son to live with the headman, but the son eventually left for "white country." When Mahalihali succeeded his father, he asked for another son to replace the one who had left, and his sister refused. In consequence he denied both sisters rights to use the dams. The sisters' sons sued unsuccessfully in a local court, which held that "no-one works land in the village and lives elsewhere" (1955: 179). The plaintiffs appealed to a higher court (a Lozi kuta), where the case was heard by nine councillor-judges.

During the hearing there was lengthy discussion of two competing Lozi rules: on the one hand, headmen have a legal right to restrict use of fishdams to village residents; on the other, kin have a moral obligation to support one another. The judges debated these issues at length, lecturing the new headman on his responsibilities to his sisters, and on the need to make peace with relatives when quarrels separate them, but attempting to balance this view with a consideration of Mahalihali's rights as headman. Gluckman notes that "though one of the most important laws in Loziland is that a headman can only be compelled to allow his own villagers to work his village land, most judges were reluctant to support him" (1955: 187). Mahalihali nevertheless continued to insist upon his legal rights. The hearing was a lengthy one, and the problem of achieving a proper balance between the rights of two competing publics (villagers and kinsmen) became increasingly complex. Finally, Solami, the head of the kuta, 
articulated a new sanction: "if Mahalihali persisted in his intransigence, the kuta would appoint a new Mahalihali" (1955: 189). This solution to achieving a just (though unprecedented) settlement was an ingenious one, in that it satisfied the interests of several different factions in this case. The kin who appealed the case won their rights to use the fishdams. At the same time, the rights of headmanship in the dams was left untouched (since the question of whether headmen in general were entitled to enforce their right was sidestepped). Further, as Gluckman notes in passing, the king had a special interest in these particular dams "because he held them in his own right and was entitled to the catch on alternate days. . . . Had the dams been given absolutely to Mahalihali, he may have lacked labour to fish them, and perhaps . . . the judge's support of his nephews was to secure the king's fish catches" (1955: 195). While Gluckman rejects this latter interpretation, it is nevertheless interesting to note that the Solami's decision successfully balanced the interests not only of the audience of kin and villagers, but of the "royal audience" as well.

In this case, then, it was the third party who transformed the dispute by changing the case from a dispute between a headman and his kin over the use of dams to one over the fitness of the headman to rule. In doing this the third party in effect created a new law (Gluckman, 1955: 189). A similar transformation occurred in the next case, Mapp v. Ohio, decided by the U.S. Supreme Court in 1961. The Mapp case is well known for its articulation of a new rule governing search and seizure in state courts. Interestingly, however, this was not the main issue argued before the lower courts and the Supreme Court. The central issue for the Ohio Supreme Court was the constitutionality of the Ohio obscenity statute; the U.S. Supreme Court in a sense converted a conflict over obscenity law into a conflict over the exclusionary rule in state criminal procedure. Strictly speaking, the Mapp case did not start as a "dispute," since it was a criminal prosecution against Miss Mapp with no victim involved. We include it here because the transformation of the case is such an interesting one; we consider the two disputants to be Miss Mapp and the State of Ohio.

The case of Mapp v. Ohio began in 1957 with the arrival of three Cleveland police officers at the Mapp residence. The officers were following up on a tip that a fugitive wanted in connection with a recent bombing was hiding in the home. However, when Miss Mapp asked what the officers wanted, 
they only said that they wanted to come in and question her, without saying about what. After telephoning her attorney, Miss Mapp refused to admit the police without a search warrant. The police then undertook a surveillance of the house; several hours later, four more police officers arrived. Police broke into the house and waved a piece of paper (which they claimed to be a warrant) at Miss Mapp, but they would not let her read it. She grabbed the "warrant" and shoved it down the front of her dress. Police then seized her, retrieved the "warrant," and handcuffed her. Miss Mapp, in handcuffs, was forcibly taken upstairs to her bedroom while the officers conducted a thorough search of the house. In the course of the search the officers discovered some obscene pamphlets and photographs. Miss Mapp was charged with and convicted of possession of these obscene materials, in violation of an Ohio state law which read in part, "No person shall knowingly ... have in his possession or under his control an obscene, lewd, or lascivious book [or] . . picture ..." (quoted in 367 U.S. at 643). As a result of her conviction, Miss Mapp was sentenced to one to seven years in the state prison.

At the trial Miss Mapp's attorney had moved to have the obscene material excluded as evidence due to the illegal nature of the search of her house. Indeed, the prosecution was unable to produce a copy of the search warrant, and could not explain its inability to do so. As the Ohio Supreme Court later admitted, the trial record suggests "considerable doubt as to whether there ever was any warrant for the search of the defendant's home" (170 Ohio St. at 430$)$. Despite the illegal circumstances of the search, the trial court had admitted the obscene items into evidence based on Ohio case law which did not mandate an exclusionary rule (i.e., under Ohio law, illegally seized evidence was admissible in criminal trials).

On appeal the Ohio Supreme Court upheld the admission of the evidence at trial. The Court noted that the conviction could have been reversed if the evidence had been obtained through shocking methods that "offend 'a sense of justice," but that no brutal or offensive force was used against the defendant in this case (170 Ohio St. at 431). Turning to the second issue-the validity of the obscenity law itself-four of the seven justices of the Ohio Supreme Court held that the obscenity law was unconstitutional by the First and Fourteenth Amendments as state interference with the freedom of speech and press. Miss Mapp's conviction was not reversed, however, due to an unusual part of the Ohio Constitution which requires 
more than a simple majority of the justices to invalidate a state statute. ${ }^{14}$

Miss Mapp's attorneys pressed the issue of the validity of the Ohio obscenity law in their appeal to the U.S. Supreme Court. The attorneys also argued that police methods used in the Mapp case were so "shocking" that the evidence obtained should be excluded as a violation of the Due Process Clause. Significantly, however, Miss Mapp's attorneys did not urge that a general exclusionary rule be applied to Ohio; they did not urge reversal of Wolf v. Colorado $(1949),{ }^{15}$ or even cite that case. But the U.S. Supreme Court reversed the conviction of Miss Dollree Mapp by overturning their 1949 decision in Wolf $\mathrm{v}$. Colorado and requiring an exclusionary rule in all state criminal trials. The Court thus used the Mapp case as a vehicle for overturning the Wolf precedent and establishing a far-reaching constitutional principle. The dissenting justices bitterly protested that the Court majority had "simply reached out' to overrule Wolf" and that there was "no justification for regarding this case as an appropriate occasion for re-examining Wolf' (Justice Harlan, 367 U.S. at 674-675). Commentators have noted that there is surely some truth in this charge (Allen, 1961: 22; Cortner and Lytle, 1971). But the Supreme Court majority defended its action in part by referring to the brief submitted by the amici curiae, the ACLU, and the Ohio Civil Liberties Union, in support of Miss Mapp. This brief did request that the Court re-examine and overrule Wolf, but the request came in a short concluding paragraph without supporting argument, and the bulk of the brief stressed other issues. ${ }^{16}$ Nevertheless, the five-man majority of the court ${ }^{17}$ was

14 The Ohio Constitution required "the concurrence of at least all but one of the judges" of the Ohio Supreme Court in order to declare a state law unconstitutional, except in the case of an affirmative ruling on unconstitutionality by the Ohio Court of Appeals (quoted in footnote 3, 367 U.S. at 673). Since the Ohio Court of Appeals had not invalidated the obscenity statute, the vote of four out of seven of the judges on the Ohio Supreme Court was insufficient to hold the statute unconstitutional.

15 In Wolf v. Colorado the Supreme Court stated that the Fourth Amendment did apply to the states, but that the states were not required to adopt an exclusionary rule to deter police and protect citizens from illegal searches.

16 The entire paragraph, which came on page 20 of their brief, stated: This case presents the issue of whether evidence obtained in an illegal search and seizure can constitutionally be used in a State criminal proceeding. We are aware of the view that this Court has taken on the issue in Wolf v. Colorado (1949). It is our purpose by this paragraph to respectfully request that this Court re-examine this issue and conclude that the ordered liberty concept guaranteed to persons by the due process clause of the Fourteenth Amendment necessarily requires that evidence illegally obtained in violation thereof, not be admissible in state criminal proceedings [quoted in footnote 5, 367 U.S. 673]. 
able to justify its action by reference to an argument raised by concerned publics represented in the brief. Note that it was the Court, however, and not the publics from which it drew its support, that articulated this new normative framework for viewing the issues in Miss Mapp's case. ${ }^{18}$

The expansion of Mapp v. Ohio resolved Miss Mapp's quarrel with the state of Ohio as to whether she should go to prison. But the Court only settled the issue about evidence obtained from an illegal search, and did not resolve the conflict over the validity of the Ohio obscenity law. The Supreme Court's decision did, however, have enormous impact in articulating a new constitutional standard for the states and in encouraging other legal challenges to state criminal procedures based on a broadened view of constitutional requirements. As Allen (1961: 47) wrote at the time, "The Mapp case represents the Supreme Court's most ambitious effort to affect and determine the quality of state criminal justice."

Although the decision of Mapp v. Ohio involved the creation of a new legal rule, it is important to note that dispute expansion does not always result in rule change. Expansion refers to the assertion of a new ordering or definition of the issues in a particular dispute; this new definition carries the possibility of general normative change for the society, but actual rule change will depend on other factors such as timing, the political context of expansion, the extent of support for the new framework, and so forth. For example, in the case of the Headman's Fishdams, the judge asserted new powers for the kuta to remove a headman, but Gluckman's material does not reveal whether or not those powers were ever referred to or anticipated in later actions. That is, we do not know the extent

17 The Supreme Court's decision was 6-3 to overturn the conviction of Miss Mapp. But only five justices based their decision on overruling Wolf; the sixth, Justice Stewart, agreed with the dissenters that the Mapp case was not an appropriate one for re-examination of Wolf, but nevertheless voted to reverse the judgment against Miss Mapp because of unconstitutionality of the Ohio statute.

18 The transformation by the Supreme Court in the Mapp case involves two sets of changes. On the one hand, the Court actually shifted the framework of argument from the obscenity issue (considered primary by the state appellate court) to the issue of search and seizure. On the other hand, within the context of search and seizure, the Court expanded the due process requirements from those considered by the Ohio trial and appellate courts (which were in the framework of Rochin v. California) to the stronger standard invoked by the overruling of Wolf $\mathrm{v}$. Colorado. Both changes illustrate Richardson and Vines' general point on shifts in the substance of a case as it moves through the appellate courts: "one of the important political functions of the appellate process . . . is . . . the transformation of cases that were routine trial types in the district into cases with greater political significance as civil liberties issues" (Richardson and Vines, 1968: 105). 
to which the judge's action redefined power relations or set new precedent. Expansion is an extremely useful concept precisely because it may provide a link between data on dispute resolution and subsequent change in the public order.

The debate over the new public law litigation is relevant here. Litigation over conditions in prisons, mental hospitals, and public schools essentially requires that trial court judges create their own normative frameworks for defining the issues in dispute. As Chayes (1976: 1297-1298) writes, "with the diffusion of the party structure, fact issues are no longer sharply drawn in a confrontation between two adversaries, one asserting the affirmative and the other the negative. The litigation is often extraordinarily complex and extended in time, with a continuous and intricate interplay between factual and legal elements. . . . The scope of the fact investigation and the sheer volume of factual material that can be exhumed by the discovery process pose enormous problems of organization and assimilation. All these factors thrust the trial judge into an active role in shaping, organizing and facilitating the litigation" (1976: 1297-1298, emphasis added; see also Eisenberg, 1978: 426-431). Judges in public interest litigation are not only developing a new ordering of the issues, but through this new ordering may be bringing about a significant redistribution of power (see also Eisenberg and Yeazell, 1980)..$^{19}$

In practice it is almost inevitable that courts will exercise social control in the process of resolving individual disputes (Shapiro, 1975: 333). An interesting question, then, is: under what conditions will courts (or other third parties) develop new ways of looking at disputes, ways that may not draw on traditional assumptions and norms but instead invoke a different social ordering? March (1956) suggested this line of inquiry in his critique of Gluckman's (1955) book on the Barotse judicial process. March noted that decision màkers do not always restrict themselves to the alternatives presented them, and he cited the case of the Headman's Fishdams as a "striking example" of a judge creating a new alternative to solve a serious problem. March then posed such fundamental questions for the study of judicial processes as: "Under what

19 Eisenberg and Yeazell (1980) argue that the courts' role in public law litigation is not so new or extraordinary when compared to procedures and remedies that courts have developed since the twelfth century. What is new, they suggest, are the kinds of rights being protected and the direction of the redistribution of power; hence, debate should focus on the substantive issues rather than on the procedural ones. 
conditions will an institution or an individual attempt to expand the set of alternatives considered? What are the mechanisms that induce the acceptance of a new alternative? Who is likely to pose new alternatives?" (1956: 534).

\section{Expansion by Supporters}

A familiar example of expansion by a supporter in American courts is the lawyer representing an individual litigant for the purposes of furthering a group interest or vindicating a social principle (see Casper, 1972). The lawyer may be formally tied to an organized interest group or may, individually, seek to advance a group interest. As Casper (1972: 158) points out, either way the lawyer is using the litigation of a discrete dispute to pursue a particular policy outcome. In addition to the activity of lawyers, interest groups themselves quite often are agents of expansion through financial support of litigation, public statements, and circulation of information to endorse an expanded view of a dispute. This is illustrated in the next two cases.

The case of the Quadriplegic Father (Hager, 1979: 3, 32) involved a disabled father who had lost custody of his two sons in a divorce proceeding. The trial court in Los Angeles emphasized the father's physical disability to reach the conclusion that the father could not have a "normal relationship" with his sons; custody was thus awarded to the mother (in spite of the fact that the boys had been living with the father, and the mother had not seen them for five years prior to the divorce). The California Supreme Court overturned the order, holding that "the trial judge had focused too narrowly on [the father's] physical condition" (Hager, 1979: 32). The state Supreme Court instructed judges in future custody cases to view handicapped persons "as individuals," considering emotional, intellectual, and other factors in deciding parental fitness and not placing undue importance on physical abilities. The Court was unanimous in its vote, and Justice Mosk wrote an outspoken opinion which "condemned as 'false and demeaning' the presumption that a handicapped person could not be a good parent" (Hager, 1979: 3).

The father was represented by lawyers from the Western Law Center for the Handicapped. But notwithstanding this successful challenge to a commonly held bias against handicapped persons, the rights of the quadriplegic father are still unclear. The Supreme Court of California sent the case back to the trial court for further proceedings, noting that any 
"additional circumstances" that had developed during the appeal should be considered in determining the best interests of the children. During the two years since the divorce, the boys had been living with their mother in New York, so it was by no means certain that the father would finally be awarded custody. We do not yet know what the broader consequences of this lawsuit will be, since the case is part of a political struggle to increase the power and legal rights of a specific group in society. Lawyers for the Western Law Center for the Handicapped urged the California Supreme Court to redefine handicapped persons as belonging more within the category of normal persons. Through such litigation the interest group helped to put the problems of the handicapped on the political agenda and to legitimate their claims.

In the case above, the third party accepted the expanded definition of the dispute, but political constraints and constraints from the specialized discourse may inhibit such a third-party role, as in the case of the Underpaid Nurses (Bennetts, 1979: 20). A widespread norm, supported by federal legislation and administrative agencies, states that there should be "equal pay for equal work." But women's earnings are, on the average, 57 percent of men's, a gap that has remained for decades. Further, "women who have completed four years of college earn less than men who have completed the eighth grade," according to economist Frances Hutner (quoted by Bennetts, 1979: 20). The main problem is that occupations are significantly segregated by sex, with jobs typically held by men receiving higher pay than those held by women. Women's rights activists are now attacking that underlying problem with test cases designed to present a new normative framework for ordering disputes over wage discrimination. The expanded concept is that of "equal pay for work of comparable worth." In a recent Colorado case a group of nurses sued the city and county of Denver charging sex discrimination. They alleged that "jobs should be evaluated according to the skills and responsibilities required and that jobs of 'equal value' or 'comparable worth' should be compensated equally, even though they may be different in nature" (Bennetts, 1979: 20). As an example of the discrimination involved under this new definition, one of the plaintiffs (who is now assistant dean of a nursing school) pointed out that "tree trimmers, sign painters, and parking meter repairmen, among others, were all paid more than nurses" (Bennetts, 1979: 20). 
The implications of adopting a "comparable worth" norm are substantial. The federal judge in Colorado dismissed the nurses' claim without a hearing, saying, "This is a case which is pregnant with the possibility of disrupting the entire economic system of the United States of America. . . I'm not going to restructure the entire economy of the U.S." (Bennetts, 1979: 20). Other test cases on this issue have similarly been rejected by courts; recently the U.S. Supreme Court declined to hear an appeal in the Denver case (Greenhouse, 1980: A17). But the plaintiffs in these cases had been unable to get a court hearing; no judge thus far has been willing to stretch the legal concept of "equal work" to encompass fact situations involving work of "equal value." "No legal handle currently exists" to facilitate litigation on the problem (Berger, 1980: 33). Interest group litigation on behalf of women in low-paying jobs has continued to press for that "handle," however; and indeed one lower federal court has just ruled that a lawsuit may proceed on a comparable worth theory (Greenhouse, 1980: A17).

Even though the Denver nurses lost in their court appearance, such cases may be succeeding nonetheless in persuading people to consider alternative formulations of the problem of income inequality for male and female workers. By creating a new configuration of facts, with nurses compared to sign painters, the women's rights advocates may get people to question traditional categories and taken-for-granted assumptions. The case of the Underpaid Nurses illustrates one stage in a lengthy and subtle process. But it may take a particularly dramatic event or the creation of a good metaphor to accelerate a change of this kind (see Edelman, 1971: 72).

The idea that supporters may play a significant role in redefining disputes applies also to nonindustrial societies where individuals or groups seek to expand individual disputes as a means of pursuing broader political interests. The Tha Murder Case (Engel, 1978: 145-148) illustrates expansion pursued by supporters in one of the hill tribes of Thailand. A 22-year-old man from the Karen tribe was found shot to death in the forest near the fields of the neighboring Meo tribe. The mother of the Karen tribesman brought a lawsuit against the Meo owner of the field in the centralized Thai court some distance from the hill tribes. The suit occurred in the context of increasing competition and hostility between the tribes due to population increases and insufficiency of land. Engel notes that the murder "served to mobilize the Karen community against the Miao encroachers" (1978: 147). The Karen 
encouraged and supported the plaintiff in the dispute, believing "that if they won the case then the Miao would be afraid of them, and would move their village away.... the Karen would then have enough land for their people and nobody would bother their land any more" (Nusit 1970: 17; quoted in Engel 1978: 147).

Engel notes that the case ended "anticlimactically" eight months after it had begun. The Karen community could not sustain its broader definition of the case in terms of conflict with the Meo tribe, Engel suggests, because of the distances involved to reach the court, the time and money involved, and the Karen's realization of the weaknesses of the specific case. The murder case itself was "effectively mediated and resolved" according to Engel (1978: 148). It is quite likely that the Thai court endeavored to rephrase the dispute into the discrete, limited parts of a murder case and thus avoid the larger issues of social conflict between the two tribes. Had the local audience of Karen tribesmen been less physically distant, and had their conflict with the Meo been perceived as more immediately threatening by Thai authorities, the expansion of this dispute might have had a greater chance of success. This suggests that the lack of a connecting bridge between the local public and the third party in this case may have affected its outcome, although (as in the case of the Underpaid Nurses) this case may be part of a process through which this bridge is being created.

\section{Expansion by an Audience}

In the cases above, a strong individual or organized group actively and consciously advanced a new definition of the particular dispute. In this section we consider the expansion of a dispute through the involvement of a more diffuse group-a broad audience that, through its attention and concern, expands the framework of the dispute. The channels of communication are especially important for explaining the dynamics of this type of expansion, since the control over those channels influences the extent to which a wider audience can be mobilized. For example, the gossip network of a small fishing village or the mass media in modern society play a key role in developing an audience which affects the course of a dispute. The following case documents a struggle between a community elite which seeks to impose its own folk system of norms on a dispute, and others in the community who attempt to redefine the dispute in the light of their own concerns. 
Gossip is the vehicle through which this struggle is carried out. As in many face-to-face societies, criteria set by the gossipers serve to define cases and shape outcomes, particularly where morals are at issue.

The case of the Deviant Mechanic (Yngvesson, 1976: 164167) took place in a Scandinavian island fishing community (Rock Island). The case involved a self-trained mechanic, Albert Cooper, who was popular with the island children and often gave them rides to a remote beach at the tip of the island. Although the younger children enjoyed swimming with Albert, twelve- and thirteen-year-old girls "began complaining that Albert was pestering them to go swimming out at Pebble Beach and that he insisted there that they bathe without swimsuits" (Yngvesson, 1976: 164). As was typical of dispute processing on the island, the case was not aired in a public forum; rather, the behavior of Albert Cooper was the subject of island gossip. Gossip served to focus opinion but with an interesting shift, after a number of years, over which gossipers' definition of the situation prevailed. Gossip was carried on in private homes, over coffee, and at the post office. There were different gossip networks in the village, determined in part by birth and kinship status, but there were overlaps between these networks created by cross-cutting allegiances (husbands' membership on same fishing team, friendship based on age of children, etc.) and by certain pivotal persons (e.g., the postmistress) who linked networks.

In this case, gossip focused on whether Albert Cooper's behavior with the young girls could be considered "normal." During the early years of the dispute, members of the island's most prestigious kin group (who actually controlled the definition of morality in the village) were dominant in defining the case. Albert Cooper was a fifth-generation resident of the island and a member of this kin group. Through careful manipulation of the gossip networks, members of this group established Albert's behavior as "normal," stating simply "he is that way," or referring to the fact that Albert had run naked since he was a child in the rocky uninhabited areas of the island (Yngvesson, 1976: 165). By a prudent choice of persons outside their immediate network (such as the postmistress) as an "audience" who could relay information to a broader island public, Albert's kin were able to control island opinion. As Paine (1967: 283) notes, "The concepts of confidence and audience are both crucial" to an understanding of gossip. An individual gossiper distributes information in a selective way, 
to a selected audience, with a view to heightening his control over message routes and to assure that his definition of the situation prevails.

Some of the island women disagreed with the excuse provided for Albert's actions, but these women were either born off the island or otherwise had low standing on the island social scale. Consequently, a definition of the case as, in effect, "no case" prevailed for several years, and Albert's pestering of young girls continued. Finally, however, a series of other actions by Albert Cooper (adultery and public opposition to a common island stand on a nature reserve) precipitated a redefinition of the case as "serious" (again via gossip). A broader island audience with information and opinions about Albert began to circulate its views, and the original objections to Albert's behavior by the less prestigious island women began to acquire legitimacy. Then, at an Island Council meeting, one of the fishermen publicly criticized Albert Cooper for his opposition to the nature reserve. He stood up in the meeting and loudly announced that "There is only one person in this room who is against us and for the reserve, and he is sitting right behind me!" (Yngvesson, 1976: 69). This brief but dramatic speech was symbolically an important event in this case. It was made by a politically prominent, but socially "fringe" fisherman in the community. It was made possible by the fact that sufficient disapproving gossip had been circulated about Albert. At the same time, the speech served as a catalyst of public opinion, producing much more noticeable overt public response to Albert in the way of stares and avoidance. The speech was able to accomplish this because the imagery it used reclassified the dispute, which previously had been defined (by the elite) as an "odd but normal act by one of our own," into an act committed by "someone who is not one of us." The imagery of islanders and mainlanders, fishermen and others, "one of us" and "them" was frequently used on the island as a means of articulating group identity, and thus it was an effective way of solidifying the increasing unease with Albert's behavior into more overt action. While this action did not suddenly effect a shift in Albert's social standing, over a period of time his isolation increased and came to resemble the ostracism imposed on serious rule breakers. In a community of this kind, this is the ultimate-and socially most devastating-form of sanction imposed.

Conflict-management processes similar to these are reported for other face-to-face communities where gossip and 
public disgrace provide effective methods of social control. In these communities public opinion, formed through gossip networks, and modified through the actions of structural outsiders such as the fisherman (or a Welsh youth group, Peters, 1972), acts as a mechanism for redefining persons and events.

The next case of expansion by an audience is the converse of the process of increasing audience involvement. In the case of the Incestuous Lovers (Pospisil, 1969: 208-229) it is the loss of interest by an audience which precipitates a redefinition of the case. A prestigious headman among the Kapauku Papuans of West New Guinea fell in love with his paternal parallel cousin, who happened, however, to belong to his own "sib." The Kapauku define a marriage within one's own sib as incestuous, and consequently the headman eloped with his lover and fled to the bush. The girl's father, a headman of greater political influence than the offender, ruled that his daughter and her seducer should be punished by death. ${ }^{20}$ Together with the patrilineal kin of the seducer, he searched widely for the couple, but was not successful. While the search was going on, the parents talked each evening "in front of a large audience of their neighbors . . . about their dilemma-having to do justice and, by this very act, killing their close relatives" (Pospisil, 1969: 213).

Pospisil notes, however, that as time passed, both pursuers and audience grew tired of this game. Further, he suggests that "the noninvolved witnesses of the man hunt played the most important part in this affair: they were the ultimate umpire, who were expected to decide when enough effort had been expended in hunting the fugitives and when the requirements of morality and justice had been satisfied. Indeed, they constituted what Durkheimean enthusiasts would call the group mind, or public opinion. The guilty couple's maternal relatives on one side and the couple's patrilineal relatives on the other were scrutinizing the mood of this noninvolved audience. Both groups of adversaries waited for the moment when the bystanders would get tired of the futile game and suggest a settlement" (1969: 213-214). Pospisil points to the importance of the role of the girl's father in the process of manipulating the audience: "his brilliant performance as an indignant and vengeful father slowly changed to that of an

20 In this case the "dispute" can be seen as conflict between the seducer/headman and the father of the girl, presented to an audience which acts as the third party in the case. 
ostensibly subdued man, 'crushed by public opinion' and by the futility of his attempts to administer justice" (1969: 214).

In this case, as in the preceding one, a dramatic speech or performance pulled together diffuse public opinion into a more articulate or explicit "statement" which transformed the dispute. In contrast to the case of the Deviant Mechanic, however, we see here a redefinition of the case as, in effect, "no case," as a result of the audience's loss of interest (combined with a series of subsequent exchanges between the kin of the man and the woman in the case). The headman-lover kept his incestuous bride as his wife and went unpunished (Pospisil, 1969: 215). Interestingly, however, Pospisil argues that the transformation did not stop at this point, but was used by the incestuous lover as a basis for reformulating Kapauku laws of incest (1969: 215). Thus in this case we have a complex interaction of audience and one of the immediate parties to the case, which ultimately produces rule change.

In the next case, the role of the audience in expanding the dispute is precipitated not by a speech or performance, but by another aesthetic form: a vivid photograph published in newspapers throughout the United States. Our discussion of the Amish Dispute in Iowa (Rodgers, 1969) shows the expansion of a local dispute through media attention and the arousal of a wide audience. This case illustrates how a particular image can change and broaden the public to whom the dispute is relevant, and through this process redefine the dispute. 21

The Amish dispute arose in the mid-1960's between a group of Old Order Amish families and the local authorities in Buchanan County, Iowa. The Old Order Amish, a conservative branch of the Mennonites, live a simple farm life according to traditional cultural and religious values. They shun the amenities of modern life and dress like Dutch peasants of 400 years ago. Amish schools are a means of perpetuating the traditional way of life. Modern schools, which teach "science, the exposure to worldly views, organized games, plays, parties, and instrumental music" which the Amish see as "sinful or detrimental to their way of life," are rejected (Rodgers, 1969:

21 Note that our discussion of expansion thus differs somewhat from Moore's (1972). Moore discusses the concept of the "expandability of disputes," suggesting that "some disputes remain disputes between individuals. Other disputes over exactly the same substantive matters expand into confrontations of groups" (1972: 68). The enlarged context of a dispute (where groups replace individuals as the key participants in conflict) is related to our definition of expansion, but we focus on the new definition or argument about a dispute that is associated with the changed context. 
17). The Amish insistence on maintaining traditional schooling for their children has resulted in occasional conflicts with state and local authorities. Courts in various states had always sided with the government to require attendance in certified schools (Cortner, 1975: 155-158).

The dispute in Buchanan County, Iowa, arose in 1962, following a "hotly debated" school district election. The Amish expected the Oelwein school board to pay the cost of certified teachers in the Amish schools. The school board agreed to do this only if the Amish school met the same curricular standards as other schools in the district. An inspection by the Iowa state authorities of the Amish schools concluded that they could not meet state standards and that the Amish would have to pay certified teachers, as they had done in the past. The Amish then dismissed their two certified teachers and hired two Amish with only eighth grade educations (Rodgers, 1969: 25).

For the next three years the Oelwein school board and Buchanan County school district fought with the group of Old Order Amish. Some Amish fathers were taken to court for truancy because their children were attending schools which did not meet state standards; they were convicted, fined, and jailed for refusing to pay the fines. The Amish request to exempt their children from the certified teacher requirement was refused (Rodgers, 1969: 26). There were various attempts by the school board to compromise, but these were rejected by the Amish. New charges were then filed against the Amish and new fines levied; "the unpaid fines began to mount into the thousands of dollars" (Rodgers, 1969: 28).

Finally, the frustrated school board decided to use force to take the Amish children to school. The school officials, sheriff, deputy sheriff, and news reporters went to an Amish school and announced that the 28 children must come out and board a bus to go to the public school. The children ran away and "newsmen got a dramatic picture of tiny children running in fear as they climbed over, under, and through a fence to escape into adjoining cornfields" (Rodgers, 1969: 29). The picture provoked great sympathy for the Amish. Indeed, the picture so changed the course of events that once it appeared in the papers, "the school officials had lost all chance to enforce the law" (Rodgers, 1969: 29). Due to wide public concern about the issue, the Governor intervened and attempted to secure a compromise that would uphold the law and yet not infringe on the religious beliefs of the Amish. This proved to be a difficult task. 
Different participants and relevant publics held divergent views about what was the basic issue in dispute. According to Rodgers' survey (1969: 47), two-thirds of the local opinion leaders felt that the main question was an economic one; that is, "the Amish just don't want to pay for certified teachers." The local decision makers in Buchanan County similarly emphasized the financial issue in the dispute; like the opinion leaders, the decision makers did not feel that the primary question was one of religious freedom (Rodgers, 1969: 76). The local citizens in the Oelwein school district gave greater weight to a cultural definition of the problem rather than a religious or financial one. The cultural view was that the Amish feared the influence of modern education on their children (Rodgers, 1969: 46-47). Finally, the Amish themselves defined the case in a number of different ways. They stated frequently that the financial issue was important and that they could not afford certified teachers; they also argued the issue as one of religious freedom; and yet they also stressed the need to preserve their own traditional values in order to keep their children from going astray (which they feared would happen as a result of going to town schools).

The picture of Amish children and the resulting widespread attention it invoked served to define the dispute in terms of persecution of a religious minority. This definition was given little credence at the local level either by the elite (opinion leaders and decision makers) or the general citizenry, in part because they knew of other Old Order Amish in the area whose children were educated by certified teachers. How could it violate the religious beliefs of one small group of Amish in the Oelwein school district, they reasoned, when it did not for other Amish?

But the wider audience in Iowa and elsewhere in the nation were more sympathetic to the religious and cultural freedom argument. Public reaction brought financial and legal aid from concerned individuals and organized interest groups such as the ACLU. This aid gave the Amish necessary resources to continue the fight and hold out until they had won (Rodgers, 1969: 86).

Ultimately the Amish won the right to maintain their own schools. A state law, passed in 1967, allowed certain religious groups to be exempt from school standards if their religious tenets "differ substantially from the objectives, goals, or philosophy of education embodied in the state-standard law" (Rodgers, 1969: 35, quoting from the Des Moines Register). 
Perhaps the most interesting aspect of this case is not the narrow modification of the lowa code which ended the dispute in that state. Instead, it is the resultant formation of an organized lobbying group, the National Committee for Amish Religious Freedom, which pressed the broader claims of the Amish (freedom from compulsory school attendance) to victory before the U.S. Supreme Court in Wisconsin v. Yoder (1972). Cortner (1975: 158) notes that "an important consequence of the 1965 Iowa clash was that it had spotlighted the plight of the Amish for a nationwide audience and aroused sympathetic supporters to action on their behalf." Wisconsin v. Yoder built on this support. By establishing that the cultural values of the Amish were indeed integral to their religious beliefs and thus protected by the Constitution, this ruling significantly modified the existing legal framework for dealing with conflicts between state educational policy and the claims of a religious group.

\section{Summary}

The sequence of events in the Amish cases demonstrates the crucial linkage between the original dispute in Iowa and the ultimate Amish victory in the Supreme Court. The efforts of the NCARF were critical to sustaining an expanded view of the issues in dispute throughout the litigation process. The resources of the ACLU and other groups who aided the Amish in Iowa were also important, although the media were initially responsible for altering the boundaries of the original school dispute. In the Kapauku case of the Incestuous Lovers, the father of the seduced girl mobilized an audience which defined the seduction as a crime, but the same man, by playing the role of a defeated advocate of justice, primed the audience to redefine that particular seduction as acceptable behavior. As in the Amish Dispute, it was the subsequent action of a party experienced in the manipulation of the legal system (who, in the Kapauku case, happened to be the seducer himself) which sustained the original impetus created by the case through to a redefinition of legal and social norms.

In our society, organized interest groups play an influential role in pressing for political and legal change, and they may be the most likely ones to seek dispute expansion. But others may play this role, expanding disputes by adding new issues, by enlarging the arena of discussion, or by increasing the number and type of active participants. Important questions about dispute expansion include: who is the participant most likely to seek to expand a dispute? Under what conditions will 
an individual or group attempt an expansion? And how do expansion processes vary across different societies?

\section{CONCLUSION}

Our principal goal in this paper has been to develop an analytical framework, applicable across cultures, for relating the management and outcome of individual disputes to the maintenance and change of broader patterns of social order. Such a framework would bridge conventional distinctions between court and non-court disputing. We suggested that disputing be viewed as a bargaining process in which the object of the dispute, and the normative framework to be applied, are negotiated as the dispute proceeds. Our approach emphasized the ways in which disputes are transformed as they are negotiated; we have paid particular attention to processes of narrowing (through which conventional normative approaches to acts and relationships are reiterated) and expansion (through which new normative orientations are imposed).

Since transformations tend to be dominated by the powerful, and since those in power typically have a vested interest in the existing social order, most disputes will be transformed by narrowing. We pointed, however, to the importance of efforts by less advantaged individuals or groups to argue disputes in ways which challenge accepted definitions, and to strategies used by third parties, supporters, and others either to sidestep this challenge (as in the case of the Headman's Fishdams and the Underpaid Nurses) or to increase its significance by mobilizing broad audience support (as in the cases of the Deviant Mechanic, the Incestuous Lover, and the Amish Dispute).

We found that it was particularly important to identify the agent of transformation. In addition, it was crucial to understand the social context of disputing. Thus we moved away from the dyad/triad distinctions, which have been central in much of the literature, to a conceptual framework encompassing relevant publics and audiences, allies of the disputants, lawyers and other spokesmen, as well as third parties and the disputants themselves. In re-examining cases from the ethnographic and political science literature, we found that any of these participants might play a central role in transforming a dispute. We also showed how invoking the support of a larger public can be an important strategy in dispute transformations which challenge the conventional normative order (i.e., expansion). In this way our material 
confirms Schattschneider's (1960: 17) important point that "a change of scope [of conflict] makes possible a new pattern of competition, a new balance of forces and a new result. . . ."

While audience mobilization is an important strategy for expansion in a range of social and cultural contexts, the process involved may be quite different, depending on what Kidder (1979: 297) describes as the number of "layers of intervening organizational complexity between lawmakers and the governed." Thus, among the Jale, the Kapauku, and to some extent, the Chagga (especially in the early, village-based stages of disputing), expansion through involvement of an audience is facilitated when the initial arena of the dispute overlaps with the broadest public which might become involved in transforming that dispute. On Rock Island, a relatively closed network of gossipers seemed to add a greater degree of organizational complexity, but because the language used by gossipers and others is the same, and because there are points of social contact between gossipers and audience, expansion is in principle not difficult. What is a problem in these contexts is the problem of voice. In small constituencies, as McConnell (1966) has argued, the consequences of challenging accepted frameworks may be severe, so people tend to avoid public dissent. We suggested that in these contexts, structural outsiders (such as the socially fringe fishermen or the Welsh youth group) may play an important role in the expansion process.

In contrast to these situations, the layers of intervening organizational complexity in large industrial societies (and, to an extent, in the Tanzanian context in which the later stages of the Chagga dispute occurred) are much more numerous. Here, much disputing is carried on in arenas which restrict or exclude participation by the society at large and which use a highly specialized form of discourse with which disputants as well as a broader public are unlikely to be familiar. In these situations, it is critical to have an agent of transformation who can act as a broker-one who can communicate to disputants and others, yet who is enough of an "insider" to the disputing arena to be able to translate the concerns of disputants and public into the official disputing language. An example of an agent of this kind is the lawyer for the Western Law Center for the Handicapped in the case of the Quadriplegic Father. A further requirement for expansion in social contexts characterized by this kind of organizational complexity is that of a medium (such as newspapers, television, etc.) through 
which a broader public can be reached (as in the Amish Dispute).

Organizational complexity is thus another significant variable which influences expansion strategy. Our discussion has emphasized, however, that a critical dimension of the expansion process in all organizational contexts involves phrasing or staging a dispute in such a way that support is mobilized for a new definition of events. This is facilitated, in both simple and more complex organizational frameworks, by couching new meanings in familiar symbolic forms. This is accomplished by attaching particular imagery to events or relationships in dispute or by demonstrating a similarity between fact situations that initially might appear to be different. Phrasing and rephrasing are integral to all disputing (conflict management through public agents and/or in public forums), and how a dispute is phrased may prejudge, but at the very least affects, the outcome.

A skeptic to our approach might ask: if socioeconomic forces shape the language of disputing and if that language is crucial to the outcome of a dispute, then why not focus on social determinants and outcomes rather than on a mediating variable, language? Indeed, this characterizes the work of political scientists who began thirty-five years ago to focus on the attributes and attitudes of judges, rather than on judicial reasoning and doctrine, to explain the outcomes of Supreme Court cases. It is also representative of the approach of many anthropologists who, during the same period, focused on the social correlates of particular styles of dispute management as the most productive way of explaining the disputing process. Nevertheless, the language of law-formal as well as informal systems of meaning in terms of which disputants and others argue and interact-has clear substantive importance.

Anthropologists point to the dependence of humans on their definitional or rule-making capacity-their capacity to impose a culturally constructed order on the social and physical world (Geertz, 1973b: 44). Similarly, linguists note that speech, like other social activities, requires rules of syntax and semantics "to which individual thought must be submitted if it seeks expression" (Lane, 1970: 21, quoting de Saussure). These rules (linguistic, legal, religious) certainly do not determine behavior (it is precisely the ability of humans to manipulate rules that has provided such rich material for the analyses of anthropologists, historians, political scientists, and others). Nevertheless, as Thompson (1975: 262) argues, legal rules are 
more than "a pliant medium to be twisted this way and that by whichever interests already possess effective power."

Our analysis of Jale and Chagga disputing suggests that in societies (or enclaves of societies) where written codes for behavior are lacking, struggles nevertheless ensue over the form in which events should be described. Whether a dispute should be phrased as a failure to fulfill the obligations of kinship and alliance, or as a conflict over individual rights to land, has important implications for the relative power of competing factions, and these factions (in the form of interested publics or audiences) become active in efforts to shape the definition and course of a dispute and may succeed in transforming it. Where there are written legal codes, the situation becomes more complex. As Thompson's analysis of eighteenth-century legal history suggests, law then acquires an existence in its own right, with "its own characteristics, its own independent history and logic of evolution" (1975: 262). What is critical here, as Gusfield (1977: 376) points out, is the character of law as public discourse, as an official language which legitimizes the relative power of individuals and groups in society. Public struggles to define and transform the meaning of acts and persons (e.g., of a handicapped man as a quadriplegic or as a parent, or of the use of uncertified teachers as an educational or as a religious matter) become significant because these definitions not only inform and affect social practice, but also provide the language for challenging that practice.

\section{CASES CITED}

Mapp v. Ohio, 367 U.S. $643,1961$.

Marvin v. Marvin, 18 Cal. 3d 660, 557 P.2d 106, 134 Cal. Rptr., 1976.

Rochin v. California, 342 U.S. 165, 1952.

Wisconsin v. Yoder, 405 U.S. 205, 1972.

Wolf v. Colorado, 338 U.S. 25 L ad 1782, 69 S. Ct. 1359, 1949.

For references cited in this article, see p. 883 . 